Forum Paper

\title{
Origin, Persistence, and Resolution of the Rotational Grazing Debate: Integrating Human Dimensions Into Rangeland Research
}

\author{
D. D. Briske, ${ }^{1}$ Nathan F. Sayre, ${ }^{2}$ L. Huntsinger, ${ }^{3}$ M. Fernandez-Gimenez, ${ }^{4}$ B. Budd, ${ }^{5}$ and J. D. Derner ${ }^{6}$
}

\begin{abstract}
Authors are ${ }^{1}$ Department of Ecosystem Science \& Management, Texas A $₫$ M University, 2138 TAMU, College Station, TX 77843-2138, USA; ${ }^{2}$ Department of Geography, 507 McCone Hall, No. 4740, Berkeley, CA 94720-4740, USA; ${ }^{3}$ Department of Environmental Science, Policy, \& Management, University of California, 130 Mulford Hall, No. 3110, Berkeley, CA 94720-3110, USA; ${ }^{4}$ Department of Forest, Range and Watershed Stewardship, Colorado State University, Fort Collins, CO 80523-1472, USA; ${ }^{5}$ Wyoming Wildlife and Natural Resource Trust, 500 East Fremont, Riverton, WY 82501, USA; and ${ }^{6}$ US Department of Agriculture-Agricultural Research Service, Rangeland Resources Research Unit, 8408 Hildreth Road, Cheyenne, WY 82009, USA.
\end{abstract}

\begin{abstract}
The debate regarding the benefits of rotational grazing has eluded resolution within the US rangeland profession for more than $60 \mathrm{yr}$. This forum examines the origin of the debate and the major reasons for its persistence in an attempt to identify common ground for resolution, and to search for meaningful lessons from this central chapter in the history of the US rangeland profession. Rotational grazing was a component of the institutional and scientific response to severe rangeland degradation at the turn of the 20th century, and it has since become the professional norm for grazing management. Managers have found that rotational grazing systems can work for diverse management purposes, but scientific experiments have demonstrated that they do not necessarily work for specific ecological purposes. These interpretations appear contradictory, but we contend that they can be reconciled by evaluation within the context of complex adaptive systems in which human variables such as goal setting, experiential knowledge, and decision making are given equal importance to biophysical variables. The scientific evidence refuting the ecological benefits of rotational grazing is robust, but also narrowly focused, because it derives from experiments that intentionally excluded these human variables. Consequently, the profession has attempted to answer a broad, complex question - whether or not managers should adopt rotational grazing-with necessarily narrow experimental research focused exclusively on ecological processes. The rotational grazing debate persists because the rangeland profession has not yet developed a management and research framework capable of incorporating both the social and biophysical components of complex adaptive systems. We recommend moving beyond the debate over whether or not rotational grazing works by focusing on adaptive management and the integration of experiential and experimental, as well as social and biophysical, knowledge to provide a more comprehensive framework for the management of rangeland systems.
\end{abstract}

\section{Resumen}

El debate sobre los beneficios del pastoreo rotativo ha eludido una resolución en el ámbito de la profesión del manejo de los pastizales naturales en los EE.UU. por más de 60 años. Este foro examina el origen del debate y las principales razones de su persistencia en un intento por identificar un terreno común para su resolución y para buscar lecciones sustantivas de este capítulo central de la historia de la profesión del manejo de los pastizales naturales de EE.UU. El pastoreo rotativo fue un componente de la respuesta institucional y científica a la severa degradación de pastizales que ocurrió a comienzos del siglo 20 y desde entonces se ha transformado en la norma profesional para el manejo del pastoreo. Quienes manejan el pastoreo han encontrado que los sistemas rotativos pueden facilitar el logro de objetivos de manejo diversos, pero los experimentos científicos han demostrado que los sistemas de pastoreo no necesariamente contribuyen al logro de objetivos ecológicos específicos. Estas interpretaciones parecen contradictorias, pero sostenemos que pueden ser reconciliadas si son evaluadas dentro del contexto de sistemas adaptativos complejos en los que las variables humanas tales como el fijar metas, el conocimiento empírico, y la toma de decisiones reciben la misma importancia que las variables biofísicas. La evidencia científica refutando los beneficios ecológicos del pastoreo rotativo es robusta, pero con un foco estrecho, porque proviene de experimentos en los que se excluyeron intencionalmente las variables humanas. Por lo tanto, la profesión ha intentado dar respuesta a una pregunta amplia y compleja - si se debiera o no adoptar el pastoreo rotativo - con un enfoque necesariamente estrecho de investigación de procesos ecológicos. El debate sobre el pastoreo rotativo persiste porque la profesión de manejo de los pastizales aún no ha generado un marco de manejo e investigación que pueda incorporar tanto los componentes sociales como biofísicos de sistemas adaptativos complejos. Recomendamos ir más allá del debate sobre si el pastoreo rotativo "funciona" o no, y enfocar el debate en el manejo adaptativo y la integración de conocimiento experimental y empírico, así como el conocimiento social y biofísico, para proveer un marco más amplio para el manejo de sistemas de pastizales naturales.

This manuscript originated from a symposium organized by D. D. Briske and J. D. Derner entitled, "Development of comprehensive grazing policy guidelines: a case for adaptive collaboration within the rangeland profession," held at the 62nd annual meeting of the Society for Range Management, Albuquerque, NM, USA, 8-12 February 2009.

The alternate editor-in-chief, M. K. Owens, was responsible for peer review and acceptance of this manuscript.

Correspondence: D. D. Briske, Dept of Ecosystem Science \& Management, Texas A\&M University, 2138 TAMU, College Station, TX 77843-2138, USA. Email: dbriske@tamu.edu

Manuscript received 25 May 2010; manuscript accepted 20 May 2011. 
Key Words: adaptive management, complex ecological systems, ecosystem management, grazing management, socialecological systems

\section{INTRODUCTION}

Contrasting interpretations of the efficacy of rotational grazing have existed since the mid-20th century in the North American rangeland profession (Sampson 1951; Heady 1961). An aggressive research program was implemented during the 1970 s and 1980 s in response to the claims that short-duration rotational grazing could support increased stocking rates compared to other grazing systems. These experimental results were consistent with those of earlier investigations indicating that rotational grazing does not increase plant and animal production or enhance surface soil hydrology compared to continuous grazing under otherwise similar conditions (O'Reagain and Turner 1992; Briske et al. 2008; Derner et al. 2008; Bailey and Brown 2011). However, rotational grazing continues to be valued by managers (Budd and Thorpe 2009) and promoted in popular press outlets, trade journals, and agency policy, for production, conservation, and ecological benefits (e.g., Goodloe 1969; Norton 1998; Teague et al. 2004, 2008). Although testimonials and anecdotal reports of the benefits of rotational grazing are abundant, systematic assessments and documentation are lacking; the number of cases where it has been either successful or unsuccessful is unknown. We advocate that this disconnect between management and scientific knowledge must be addressed to provide appropriate, consistent, and defensible grazing management recommendations and policies and to generate more useful knowledge of complex adaptive systems (Juntti et al. 2009).

The rotational grazing debate is one of several cases where applied ecological disciplines are struggling to resolve critical natural resource management issues in the face of tensions between experimental and experiential or management knowledge (e.g., Holling 1996). High-profile examples include global fisheries (Hughes et al. 2005; Bundy et al. 2008); northeastern forests in North America (Likens and Franklin 2009); the "pastoral crisis" of sub-Saharan rangelands during the latter half of the previous century (Ellis and Swift 1988; Oba et al. 2000); and the so-called "Rosgen Wars" in stream restoration (Lave 2009). These cases illustrate that natural resource management involves social, political, and economic components that influence and constrain practices, recommendations, and policies (e.g., Boyd and Svejcar 2009). However, the human dimensions of management decisions and outcomes have often been neglected in favor of more narrowly focused technical or biophysical prescriptions (Fortmann and Fairfax 1989; Bundy et al. 2008; Fazey et al. 2010). Consequently, management recommendations may have been formulated with insufficient experiential or experimental evidence and research programs may have inadvertently produced information that was of limited value within a management context. Management and policy recommendations derived in this manner have become institutionalized norms that have eluded rigorous scientific evaluation of their effectiveness (e.g., Pullin et al. 2003; Sutherland et al. 2004). In the case of US rangeland management, agencies such as the Forest Service have historically sought scientific authority to support socially unpopular policies and practices, even if the scientific evidence was not yet conclusive (Schiff 1962; Rowley 1985; Sayre 2010).

The persistence of the rotational grazing debate is due in part to terminological confusion; terms such as holistic grazing, planned grazing, prescribed grazing, and management-intensive grazing, in addition to various grazing systems (rest-rotation, deferred rotation, high frequency-short duration, season-long), continue to be used with multiple and ambiguous meanings despite attempts to standardize definitions (Society for Range Management [SRM] 1998). Here we define rotational grazing as the movement of livestock between two or more subunits of a rangeland such that alternating periods of grazing and no grazing (rest) occur within a single growing season (Heitschmidt and Taylor 1991). However, the vast majority of grazing experiments conducted since 1980 have examined intensive short-duration systems (Briske et al. 2008).

The goal of this forum is to examine the origin of the rotational grazing debate and the major reasons for its persistence in an attempt to identify common ground for resolution, and to search for meaningful lessons from this central chapter in the history of the US rangeland profession. We propose that resolution of the debate will require a management framework that integrates experiential and experimental knowledge to adapt to the uncertainties of managing rangelands as complex adaptive systems. This involves a more candid assessment of the nature and limits of scientific knowledge about rangeland ecosystems; reevaluation of the relationships between management, science, and policy; and development of a model of natural resource management that is more inclusive of human dimensions, including a process for the production of more useful knowledge.

\section{ORIGINS AND PERSISTENCE OF THE DEBATE}

\section{A Response to Rangeland Degradation}

The rotational grazing debate can be traced back to 1950 , when Arthur Sampson convened a "symposium on rotation grazing in North America" at the third annual meeting of the Society for Range Management. Its roots go back further still, however, to the origins of range science in the United States early in the 20th century. The profession developed alongside, and in many respects ahead of, the scientific discipline of ecology (Dyksterhuis 1955; Tobey 1981; Joyce 1993), catalyzed less by scientific discoveries than by an urgent practical matter: the widespread degradation of western rangelands in the late 19th century (Sayre and Fernandez-Gimenez 2003). Early government researchers responded to the crisis with a combination of local, observational, and experimental knowledge (Smith 1899; Bentley 1902; Griffiths 1904; Wooton 1908). The exclusion of livestock from plots or pastures was an obvious and necessary step to initiate their studies, and it was from here that rotational grazing entered into the emerging discipline of range science and management. 
Rapid, positive vegetation responses to grazing exclusion following extreme overgrazing prompted early researchers to conclude that rotational grazing would restore rangeland productivity. Early livestock exclosures revealed not so much the effects of grazing, however-though this was the overarching question-but rather the effects of grazing cessation after an extended period of severe overuse. The recommendation to rest pastures for weeks to years-but not permanently_was attractive because it offered a way to combine economic use with ecological restoration. "As early as 1895 , Smith advocated improvement of natural ranges by dividing them into separate pastures to be grazed in rotation, thereby providing for the spread of forage plants by means of ripened seed" (Sampson 1951, p. 20). In the first range science textbook, Sampson (1923, p. 61) emphasized that improving degraded rangelands_as distinct from maintaining rangelands that were already in good condition-required "a grazing system" of "alternating the grazing and the resting of the lands" (cf. Sampson 1913; Merrill 1954; Hormay and Evanko 1958).

That range science was born during a period of widespread range degradation subsequently shaped the definition of rotational grazing itself. In a later edition of his textbook, Sampson (1952) distinguished between "deferred" and "rotation" grazing on the basis of their underlying management objectives. Deferred grazing involved delaying grazing of an area "until after seed maturity" in order to encourage vegetation recovery. Rotation grazing, by contrast, involved "shifting the livestock systematically at desirable intervals to different subunits of a range area or fenced subdivisions, and back to the first subdivision, without specific provision for seed production" (Sampson 1952, p. 19, emphases in original). Stoddart and Smith (1955, p. 329) echoed this distinction in the second edition of their own, more influential textbook. Sampson (1923, p. 61) had initially declared that rotation grazing was "built on a thoroughly tested scientific foundation," but by the 1950s subsequent investigations caused him to qualify, if not quite withdraw, this endorsement. Summarizing the 1950 Society for Range Management symposium in the Journal of Range Management, he observed that "much diversity of opinion exists among both research workers and operators regarding the merits of rotation grazing" (Sampson 1951, p. 19). He reported that the limited experimental evidence available was inconsistent and in many cases confounded by terminological and other difficulties. In his textbook of the following year, he wrote that "rotation or alternate grazing...assumes that intermittent rest from grazing is beneficial to the forage cover, even though it must support more stock during the shorter grazing period. Although this assumption seems to hold in some localities or vegetal covers, it may not in others" (Sampson 1952, pp. 272-273). Stoddart and Smith (1955, p. 330) likewise characterized the benefits of rest as "not adequately proved," stating that "Although most range experiments fail to show advantages to rotation grazing, many pasture experiments and humid-climate experiments have shown distinct advantages" (1955, p. 332). They further noted that for larger ranches in low-productivity rangelands, the costs of fencing and water systems to enable rotational grazing systems were "often prohibitively expensive" (1955, p. 333).

\section{Role of Federal Agencies}

The persistence of the rotational grazing debate must be interpreted within the historical context of range science and the politics of rangeland administration in the United States. By the 1950s, the discipline had consolidated around the Clementsian paradigm of plant succession; Sampson (1919) was himself largely responsible for this, presumably a consequence of his association with Clements while pursuing bachelor's and master's degrees at the University of Nebraska (Parker 1967). This paradigm held that natural processes would invariably drive vegetation communities back toward "climax" conditions upon removal of a disturbance such as grazing (Westoby et al. 1989; Briske et al. 2005). Rangeland administration, policy, and research had by this time been institutionalized by the US Forest Service and the Bureau of Land Management, based on the successional axiom that rangeland vegetation varied along linear, reversible pathways as a function of livestock grazing intensity. This framework located control firmly within the scope of management, and it lent itself to rules of thumb such as "take half, leave half" that were easily communicated to both agency personnel and ranchers. It was not based on scientific evidence, however, so much as it was on scientific theory (Sayre 2010).

Moreover, it was the needs of agencies, especially the Forest Service, that promoted the emergence of range science as an academic discipline. Scientific authority was crucial for the agency to justify policies that routinely encountered resistance from ranchers and elected officials in Congress (Rowley 1985). Trained, credentialed, and professional staff was essential to this effort, and academic programs in range science emerged at western land grant universities to meet this demand (Chapline et al. 1944; Dyksterhuis 1955). Uniform policies and scientific paradigms that could be applied throughout the nationwide domain of the land management agencies, despite the regional and local ecological and social diversity of western rangelands (Starrs 1998), were highly desirable in terms of administrative efficiency and the creation of a professionally cohesive management cadre (Kaufman 1967). Sampson (1913) developed the deferred-rotation system while employed by the Forest Service in the early 1900s, and Hormay and Evanko (1958), also Forest Service researchers, worked with rest-rotation grazing in the 1950s and 1960s. Both efforts were conducted on western forested lands, but the results were applied across all national forests, and it was Forest Service policy for most of the 20 th century to put rotation, particularly deferred rotation, on every grazing allotment (Rowley 1985). Combined with the terminological confusion alluded to above, these factors converged to institutionalize rotational grazing as a prescriptive management norm well ahead of rigorous scientific inquiry into its effectiveness.

\section{Holistic Resource Management}

Allan Savory and Holistic Resource Management have contributed to the persistence of the rotational grazing debate for roughly $40 \mathrm{yr}$ (Goodloe 1969). Savory (1988) likened rotational livestock grazing to the behavior of wild grazers-a comparison that Clements (1920) and other early range researchers had also made-and he promoted it as a means of restoring degraded rangelands-much as Sampson (1952) 
had done. Unlike earlier proponents, however, Savory inverted the Clementsian valuations placed on grazing and rest; according to his interpretation, the "herd effects" of concentrated livestock grazing, including the impacts of hooves on soil surface characteristic and uniform use of plants, were positive tools for restoration, whereas lack of disturbance could constitute "overrest" that would result in declining soil conditions and undesirable competition among plant species. Achievement of these herd effects in ranch settings required high livestock densities, generally made possible by concentrating livestock in individual pastures accompanied by frequent rotations among pastures. High costs for fencing and water developments represented a substantial economic invested that could be recouped, it was hoped, by higher stocking rates and increased livestock production.

The claims of Holistic Resource Management proponents attracted the attention of ranchers, many of whom attended short courses put on by Savory and his Holistic Management Institute. Savory's explanation of the role of grazing, based on his observations of wildlife in Africa, was appealing and easy to understand, and for many, more compelling than the limited and somewhat inconsistent body of scientific evidence that existed at the time. Savory was widely recognized for this ecological interpretation of grazed systems, but his integration of goal setting, decision making, and financial planning into grazing management may have been of even greater value to ranching families. Holistic Resource Management also promoted cooperation among diverse stakeholders in public lands management by offering the prospect of environmental benefits as well as production increases (Bartolome 1989). In these contexts, implementation of a specialized grazing system may have conveyed an impression of progress and change, or an "increase" in stewardship that could embody and unify management actions and goals. It was the claims of ecological benefits, rather than enhanced management more generally, that became the central focus of grazing systems research in the 1970s and 1980s, which generated a large portion of the production-based research reviewed by Briske et al. (2008).

\section{HUMAN DIMENSIONS OF COMPLEX ADAPTIVE SYSTEMS}

\section{Importance of Human Dimensions}

The persistence of the rotational grazing debate reflects a discrepancy between management and science as sources of knowledge. Proponents point to examples where implementation of rotational grazing has produced benefits of various kinds. Critics respond that these examples, lacking rigorous experimental design or controls, cannot demonstrate any causal link between rotational grazing and the reported ecological outcomes, and that the available experimental evidence contradicts such a causal link. The debate eludes resolution because the evidence and definition of success are not directly comparable between the two knowledge sources. Advocates have demonstrated that rotational grazing systems can work for diverse purposes; scientists have demonstrated that they do not necessarily work for specific ecological purposes. There are at least three nonmutually exclusive hypotheses that could accommodate both interpretations: 1) variables other than the rotation of livestock in and of itself are responsible for successful outcomes; 2) distinct metrics are used to define success in science and management; and 3) the confidence that scientists place in experimental controls is misplaced in the case of rotational grazing research.

Human dimensions of grazed ecosystems were intentionally excluded from the experiments reviewed in Briske et al. (2008) because they constituted uncontrollable sources of confounding variation. The experiments involved fixed protocols as a necessary part of experimental design to isolate the effects of rotational grazing from other variables. Even if allowance was made for stocking rates to vary in response to rainfall, "management" was still strictly constrained by the need to maintain replicates and controls for the life of the experiments. This does not mean that the experiments were invalid for their intended purposes-to assess the effects of rotational grazing on selected ecological variables. However, this experimental approach removed one of the key variables of grazing management, namely, the managers themselves-their perceptions, knowledge, and ongoing decision making. The capacity for management to adapt to variable ecological conditions and desired outcomes at the local scale was excluded in order to maintain uniformity and consistency in experimental treatments across time and space.

The greater the biophysical variability of a given rangeland ecosystem, however, the more problematic the exclusion of management decisions is likely to be. High intra- and interannual variability in rangeland ecosystems means that experiments need to be at least 3-5 yr in length (or longer) to detect a treatment response relative to inherent climatic variation (e.g., Pinchak et al. 2010). However, the longer that experiments run without the ability to respond to changing conditions, the more likely they are to deviate from what would occur on working ranches, where managers respond flexibly, in real time, to the inherent spatial and temporal variability of rangeland ecosystems. A manager's ongoing adjustments to fluctuating and site-specific conditions are not completely intractable for scientists, but they cannot be fully anticipated in an experimental design; if dynamic management decisions are incorporated, researchers may be unable to differentiate between the effects of the biophysical and management variables, resulting in experimental confounding. In short, reduced flexibility in grazing experiments removes many sources of potential variation, but at the risk of becoming unrealistically abstracted from management applications. This is very likely the most serious limitation of the experimental data assessing the efficacy of rotational grazing (Briske et al. 2008).

We propose that the rotational grazing debate can best be resolved by understanding grazed rangelands as complex adaptive systems, and that viewed in this way, the evidence supporting and refuting the benefits of rotational grazing can be seen as complementary, not contradictory. All rangelands are complex biophysical systems with highly varied weather, soils, animals, and vegetation (Boyd and Svejcar 2009). Range scientists strive to understand these systems with the use of methods designed to facilitate systematic acquisition of information in a framework that minimizes human subjectivity (Stern 2005). In actual ranch settings, however, biophysical complexity is further compounded by diverse human goals, 
values, beliefs, and decision-making strategies (Stafford Smith et al. 2007). Thus, grazed rangelands are complex adaptive systems: "systems characterized by many interacting components that are capable of learning from and adapting to changing circumstances. The patterns of structure or behaviour that emerge from the interactions of the parts are not usually deducible from examining the parts" (Lynam and Stafford Smith 2004, p. 69). The specifics of decision-making models must be as reflective of the local management environment as the specifics of livestock management must be to the local ecological environment. The capacity of managers to detect, learn, and adapt to change is a key component of complex adaptive systems and this capacity should be incorporated into rangeland research programs (Lynam and Stafford Smith 2004). Range scientists have devoted much greater attention to the biophysical than to the human dimensions of grazed ecosystems; however, managers and ranchers must cope with both components and their interactions.

\section{Mental Models of Grazing Managers}

Research derived from working ranches supports the view that in complex adaptive systems, "the human processes are as important as the ecological processes" (Lynam and Stafford Smith 2004, p. 71). From a series of case studies, Lynam and Stafford Smith concluded that "mental models are a crucial slow variable" in complex adaptive rangeland systems (2004, p. 76, emphasis in original). "Managers act with the expectation of the action resulting in specific impacts. They must therefore, have and be using mental models or conceptualizations that at the very least contain cause-effect relationships" (Lynam and Stafford Smith 2004, p. 69). Mental models influence both what managers look for and see, and what they do in response. Rules of thumb such as "take half, leave half," for example, direct managers' attention to certain variables (e.g., forage utilization) and suggest certain responses (e.g., when to remove livestock). Scientists attempt to be as explicit as possible about their own mental models, and experiments are a way of identifying and testing the major assumptions. But scientists also leave certain claims implicit, and for scientists and managers who have spent decades studying a particular topic and working in a particular location, mental models may be implicit and assembled from a variety of information and experiences. In understanding rangelands as complex adaptive systems, "it may be as important to monitor the changing mental models themselves, as it is to measure grass cover, since such contextual information may determine the importance of other types of observation" (Lynam and Stafford Smith 2004, p. 71).

We hypothesize that rotational grazing can facilitate, or follow from, changes in the mental models of managers. Successful applications may reflect changes in how managers see and think about the entire process of managing their land, water, and animals. Where rotational grazing is implemented, the substantial capital investments in fencing and water may contribute to greater managerial interest and commitment to improvement of rangeland productivity, leading managers to pay greater attention to subtle ecological and socioeconomic indicators and to respond more rapidly to opportunities or hazards (Brunson and Burritt 2009; Richards and Lawrence
2009). Such changes need not be exclusive to rotational grazing, however. Consider the case of the four ranch families who participated in the Grass Bank on the Gray Ranch in the 1990s (Rissman and Sayre 2011). Three of them decided to change their management significantly when they returned to their own ranches because the experience of complete destocking for 3-5 yr had been revelatory: It had enabled them, for the first time in their lives, to observe their lands without livestock present. They saw how little forage growth took place during drought, even without grazing, and they saw how much more recovery could occur in the absence of livestock when it did rain. One might hypothesize that this kind of learning experience is a powerful way to change mental models and subsequent management actions. The varying abilities of managers to recognize and seize such teachable moments may determine the perceived value and success of rotational grazing —or any other grazing system - to a greater extent than the ecological consequences of the system (Briske et al. 2008). Likewise, grazing failures may be due to inappropriate mental models that eventually impair the economic or ecological viability of the enterprise.

To say, based on experimental research, that rotational grazing is neither necessary nor sufficient to achieve various outcomes is not to say that successful cases are impossible or nonexistent. Rather, it is simply to say that the outcomes could have been achieved with other grazing methods if management had been improved, and that they would not have been achieved if greater management and adaptation had not been associated with rotational grazing. Even ardent proponents of rotational grazing are likely to agree with this if formulated in terms of policy: Requiring all ranchers to practice rotational grazing, regardless of other considerations, is not a viable recommendation. Any such one-size-fits-all solution ignores the fundamental need to understand the unique characteristics and circumstances of each grazing program, ranch, and ecosystem, as well as the unique objectives and constraints of managers.

In other words, the implementation of rotational grazing may increase the intensity of management, leading to increased adaptation and the incorporation of experiential knowledge in subtle and unrecognized ways, without necessarily stimulating ecological functions such as plant or animal production (Briske et al. 2008; Brunson and Burritt 2009; Richards and Lawrence 2009). For example, rotational grazing can provide the flexibility needed to incorporate management practices such as fire into grazing systems (Teague et al. 2010), facilitate animal management and veterinary care (Richards and Lawrence 2009), and potentially enhance the ability of managers to anticipate and detect critical stocking-rate decisions (Briske et al. 2008). Benefits to management effectiveness, but not necessarily ecological function, most likely explain the apparent contradiction between scientific and managerial interpretations of rotational grazing. The occurrence of direct ecological benefits cannot be discounted altogether, but it has been the most intensively studied aspect of rotational grazing, and if even some components of ecosystem function were consistently improved, it should have been reflected in the integrated ecological processes of plant or animal production-but the preponderance of experimental evidence indicates that it has not (Briske et al. 2008). Suggestions that the length of grazed-ungrazed periods, 
number or size of pastures, or livestock densities were insufficient in grazing experiments indicate that if ecological benefits can be directly achieved in these systems (Teague et al. 2008), they require very specific and nuanced grazing patterns. We acknowledge that increased management intensity associated with rotational grazing may indirectly contribute to enhanced ecological outcomes in some situations. The distinction between direct and indirect outcomes is essential for devising policies and incentives to promote effective grazing management by establishing whether benefits accrue from infrastructure, management skills, or the interaction between them.

Two novel investigations incorporating management adaptation into grazing systems research offer interesting, but admittedly inconclusive, insights into the interaction of managers and grazing systems. A long-term, large-scale investigation in north-central Texas that incorporated elements of adaptive management (e.g., livestock rotations among pastures were based on percentage forage utilization) showed a modest increase in herbaceous production $(8.5 \%)$ and a substantial increase in ground cover $(27 \%)$ on the most productive sites, but not on less productive sites, in an eight-pasture rotational system compared to continuous grazing (Teague et al. 2010). Although these positive herbaceous responses did not result in increased livestock production in the rotational system compared to continuous grazing during the 7-yr investigation (Pinchak et al. 2010), neither was livestock production reduced when rotational grazing was used to provide sufficient deferment-effectively increasing stocking rate $12-20 \%$ per year-to support prescribed burning for woody plant control. An investigation in the flooding pampas of Argentina was designed to capture the full complement of adaptive management by investigating vegetation responses on existing ranches that had employed rotational and continuous grazing (Jacobo et al. 2006). Improved species composition occurred on a midslope site, and vegetation cover increased on both the midslope and lowland sites. Unfortunately, neither plant or animal production were presented in this investigation, but the authors suggested that rotational grazing systems could sustainably accommodate a stocking rate $60 \%$ greater than the regional average. Moreover, both of these investigations, when compared to those where experimental designs excluded management adaptation (Briske et al. 2008), point to the tremendous importance of adaptive management in grazing systems. The Argentinean researchers strongly emphasized the importance of flexibility and adaptive management focused on specific outcomes to the success of rotational grazing (Jacobo et al. 2006). Similarly, the Texas researchers cautioned that a period as long as $2 \mathrm{yr}$ may be required for managers and livestock to transition from continuous to rotational grazing effectively (Pinchak et al. 2010). These unique investigations support our premise that increased management attention and adaptation, including the establishment of clearly defined goals, makes the grazing system, rather than the other way around.

\section{BEYOND THE DEBATE: ADAPTIVE MANAGEMENT OF COMPLEX SYSTEMS}

Given that the adaptability and cumulative knowledge of managers is essential to effective grazing management, we recommend that the rangeland profession shift its attention from debating the effectiveness of any particular grazing system to a broader examination and discussion of the processes that contribute to adaptive grazing management (e.g., O'Reagain et al. 2009; Grantham et al. 2010; Torell et al. 2010; Bailey and Brown 2011). If rotational grazing tends to promote management attention and improve knowledge acquisition, which in turn leads to adaptation and better management, can we identify the essential lessons of this process and apply them more broadly, with or without a specific grazing system? Can we understand how people develop site-specific management strategies that are responsive to spatial and temporal variability, incorporate both experiential and experimental knowledge, cope with the high levels of uncertainty characteristic of rangeland ecosystems, and address the interface between human dimensions and grazing management (Blackmore 2007; Fazey et al. 2010)? A management framework should facilitate learning, and the subsequent adjustment of mental and system models, through detection of change and response in multiple variables, acquisition and archiving of multiple forms of information, and testing of alternative strategies (Holling 1978; Grantham et al. 2010). To adhere to a single set of practices is neither adaptive nor sensitive to the complex interactions that characterize managed rangelands.

\section{Approach and Goals}

Adaptive management was originally proposed to incorporate the principles of scientific experimentation into the design and implementation of natural resources management (Holling 1978; Walters and Holling 1990; Murray and Marmorek 2003). Adaptive management recognizes uncertainty as inherent in natural resources management and seeks to learn from it, rather than attempt to eliminate or control it. In practice, adaptive management programs range from relatively simple approaches that emphasize monitoring of existing management outcomes, to more elaborate experimental designs with replication and multiple management treatments. All approaches emphasize a full cycle of design, implementation, monitoring, interpretation, and revision of management practices to incorporate new information into the management process explicitly. The adaptive management model as proposed by Holling (1978) and adapted for stakeholder participation (Fernandez-Gimenez et al. 2008) may offer a way to enhance management on rangelands more broadly.

The adaptive management model specifies a design phase in which the goals, hypotheses, and management practices to be evaluated are determined. For a single ranch, the number of people involved may be few, perhaps an individual or a family. For larger areas, or on public lands, multiple and diverse stakeholders may be involved, from individual citizens to other agencies and public interest groups. Where there are multiple stakeholders, the adaptive management framework identifies key points to focus deliberations and creates a space for mutual learning (Fernandez-Gimenez et al. 2008). Participatory or collaborative adaptive management brings together agencies, land managers, other stakeholders, and scientists 1) to identify shared goals, management objectives, and research questions collectively, 2) to agree upon practically feasible and scientifically robust ways to answer questions while advancing 
management objectives, and 3) to design collaboratively, to carry out the design, and to interpret the results of monitoring strategies to assess the outcomes of management practices. Multiple stakeholder involvement in the design and implementation of research and interpretation of results can enhance the value of research to local management needs and identify solutions to the most pressing management questions.

A key element of the process is the development of an explicit model of the system under consideration, which should include social as well as ecological components and relationships. Making stakeholders' mental models explicit, and creating a shared model, is important for clarifying potentially conflicting assumptions about system behavior, identifying uncertainties or gaps in knowledge, generating testable hypotheses and alternative management practices, and selecting appropriate indicators and measures for both outcome (dependent) and explanatory (independent) variables. This process represents an opportunity to link science and management more effectively by ensuring that goals, indicators, and outcomes are meaningful to all stakeholders. In addition, the model-creation process is likely to reveal explanatory variables related to managers' decision-making processes that have been overlooked in past studies of grazing systems. An additional benefit is that creating a shared model entails significant dialogue and communication among the participants, which initially helps diverse stakeholders to understand each others' knowledge, values, and perspectives, and eventually can lead to stronger relationships and greater trust and respect (Klein 1996; Lele and Norgaard 2005; Thompson 2007). Similarly, participation of agency specialists and managers, together with scientists in monitoring design, data collection, and interpretation of findings, lends credibility and legitimacy to the results, and increases the likelihood that these distinct groups will accept and adopt the resulting recommendations.

\section{Barriers to Adoption}

Institutional barriers often pose major challenges to successful implementation of collaborative adaptive management, especially within federal natural resource and land management agencies (McLain and Lee 1996; Moir and Block 2001; Stankey et al. 2003). Institutional cultures influence behavior patterns of personnel, approaches to problem solving, and the establishment of programmatic goals and priorities (Cortner et al. 1998; Boyd and Svejcar 2009). Institutional barriers to collaborative adaptive management include lack of commitment to the process and aversion to risk entailed in experimentation and innovation (Miller 1999; Stankey et al. 2003); lack of resources for longterm monitoring (Moir and Block 2001); insufficient decision space for experimentation and adaptation due to existing laws, policies, and regulations (Stankey et al. 2003); inability to manage across jurisdictions; and failure to involve relevant stakeholders (Cortner et al. 1998). These barriers may contribute to the unfortunate consequence of "programmatic outcomes replacing the intended ecological outcomes as the primary management objectives" (Boyd and Svejcar 2009, p. 494). As suggested previously, we are concerned that rotational grazing has often become the programmatic end, rather than a means to achieve specific ecological, production, and economic outcomes from grazing management.

\section{ARE THERE LESSONS TO BE LEARNED?}

What lessons may be learned from this central chapter in the history of the rangeland profession-not only to resolve the rotational grazing debate, but also to reduce the likelihood of similar impasses in the future? Analysis of the debate from the perspective of complex adaptive systems indicates that the profession has attempted to answer a broad, complex question-whether or not a manager should adopt rotational grazing - with necessarily narrow experimental research focused exclusively on ecological processes. Question formulation within the context of a simple rather than a complex problem, in the absence of many management considerations, establishes why the rotational grazing debate has appeared intractable and has persisted as long as it has. We envision three professional issues as underpinning the rotational grazing debate and suggest that they must be acknowledged and at least partially resolved to increase the effectiveness of both rangeland management and the generation of more relevant knowledge within the profession.

\section{Distinguish Between Simple and Complex Problems}

Fundamental to both the persistence and resolution of the rotational grazing debate is the framework or context in which it has been conducted. The question, "Does rotational grazing work?" implies a simple yes-or-no answer, and therefore a framework defined by linear relationships between management variables and ecological outcomes that possess a high degree of predictability (Boyd and Svejcar 2009). This is partially a consequence of the single-minded objective of recent grazing experiments to test the claims of Allan Savory, but it also reflects a framework that is inherent in the narrowly focused technical approach to management that has characterized the rangeland profession throughout much of its history (e.g., Fazey et al. 2010). In contrast, the management of grazed ecosystems presents a complex problem defined by multiple variables whose interrelationships may vary in both time and space with limited predictability (Boyd and Svejcar 2009). Effective management of grazed ecosystems is sufficiently dynamic and complex that it should not be envisioned to have any one correct solution; rather, effective management requires an ongoing, dynamic, and systematic approach to decision making that identifies opportunities, constraints, and potential outcomes. The concept of targeted grazing represents an important step in this direction by explicitly emphasizing management outcomes (Launchbaugh and Walker 2006).

An important related consideration is that models of reality (e.g., the Clementsian theory of succession) not become a reality of models-that is, that we not mistake models as more than heuristics for improving knowledge. This is a common source of error in many sciences; treating complex systems as though they were simple is not only reductionist, it also tends to promote an exaggerated estimation of the strength of our models (Shrader-Frechette and McCoy 1993).

We recognize that most rangeland professionals do see grazing management as a complex problem, and we surmise that they evaluate specific grazing systems in ways that implicitly incorporate other relevant variables and actions associated with effective grazing management. Nonetheless, we 
are concerned that excessive emphasis of the technical aspects or infrastructure of grazing systems may inadvertently mask or exclude evaluation of other important considerations, including adaptive management and ecological outcomes. The ambiguity associated with this technological approach may have compromised our ability to interpret the behavior of grazed ecosystems in the broader context of complex adaptive systems.

\section{Monitor Outcomes of Management Practices}

Outcomes of management practices need to be systematically monitored, at least in representative cases, both to document their effectiveness and to provide feedback to improve their efficacy in the context of adaptive management. Monitoring outcomes of various practices in a management context can contribute to more rapid development of local ecological knowledge than more traditional forms of experimental research (Lynam and Stafford-Smith 2004; Juntti et al. 2009) and it should be recognized and implemented as a central component of integrated natural resource management (Nichols and Williams 2006). The profession can no longer afford merely to anticipate specific outcomes from management practices in an era of increasing accountability and critical evaluation by various stakeholder groups (e.g., Toombs and Roberts 2009). The spatial and temporal heterogeneity of rangelands coupled with highly variable management inputs minimizes the likelihood that a given management practice will consistently produce similar outcomes in all cases. In the absence of systematically collected monitoring data, we have minimal documentation of the outcomes from rotational grazing beyond those reported by the research community, even though agencies such as the Forest Service have implemented it for the better part of a century. This deprives the profession of a documented source of management knowledge to compare and integrate with experimental knowledge to promote understanding of the behavior of complex adaptive systems.

\section{Integration of Social and Biophysical Components}

Complex adaptive systems contain both social and biophysical components and drivers that interact in complex and often unpredictable ways (Lynam and Stafford Smith 2004; Stafford Smith et al. 2007). Even in cases where a great deal is known concerning the ecological function of a system, it does not necessarily ensure successful management outcomes because this information represents only one portion of the knowledge required to manage effectively (Blackmore 2007; Grantham et al. 2010). Social institutions and policies may dictate management actions that are inconsistent with ecological goals, and environmental changes can in turn influence social institutions and policies. Undesirable outcomes often result when social and ecological components and processes are mismatched in ways that minimize learning and inhibit management adaptation (Lynam and Stafford Smith 2004; Stafford Smith et al. 2007). For example, the consequences of short-term economic decisions on long-term ecological outcomes are often not fully recognized, and institutional policies often focus on the immediate social-environmental consequences without addressing the long-term social-ecological drivers responsible for the problem.
Recognition of rangelands as complex adaptive systems emphasizes the need for rapid integration of experimental and experiential knowledge, as well as social and ecological knowledge, to increase our effectiveness in developing meaningful management and policy recommendations and to promote generation of more relevant knowledge (Lynam and Stafford Smith 2004; Blackmore 2007; Stafford Smith et al. 2007; Juntti et al. 2009). Science can contribute systematically derived information to identify limits and critical reference points for ecological and social processes and relationships (Stern 2005). Management provides the essential capacity to anticipate and manipulate variables within the confines of these ecological and social limits and relationships to pursue desired outcomes. A management system should provide the opportunity to learn from science, monitoring, and diverse sources of information. Social sciences need to become an integral component of the rangeland profession, and the role of human dimensions needs to become a central component of rangeland research. Social scientists can facilitate identification of our individual and collective mental models, increase insight into our professional cultures and associated social institutions, and inform research approaches to generate knowledge that is more relevant to rangeland ecosystems.

\section{MANAGEMENT IMPLICATIONS}

Rotational grazing became established as the professional norm for grazing management early in the US rangeland profession as an institutional initiative to restore degraded rangeland. This grazing system, as well as others, may convey various direct benefits to management effectiveness and indirect benefits to ecological outcomes when coupled with the ability of managers to observe and adapt, but both categories of benefits have yet to be documented. Continued emphasis on rotational grazing throughout the history of the profession may have restricted a more comprehensive evaluation of both the ecological and management components of grazing management, including adaptive management and environmental outcomes, as a result of the narrow technological focus on size and number of pastures and length of rest and grazing periods. The implicit assumption is often that desired outcomes will emerge from rotational grazing without either explicit definition of specific outcomes or monitoring protocols to evaluate these outcomes. Consequently, whether the intended outcomes were attained is either not determined, or is evaluated in the eye of the beholder, without adequate verification to assure that the results were sound ecologically, economically, and socially. This deprives the profession of critical information necessary to justify its management recommendations and to revise management actions to improve their efficacy in subsequent applications.

The persistence and divisiveness of the rotational grazing debate does not bode well for the ability of the rangeland profession to address pending challenges of much greater magnitude and complexity than grazing management, including invasive species, land fragmentation, biodiversity, and climate change. We argue that the rotational grazing debate is a symptom of a much greater underlying problem within the rangeland profession - the absence of an adequate framework to evaluate and manage complex adaptive systems involving 
both social and ecological components (e.g., Boyd and Svejcar 2009). Collaborative adaptive management is not a panacea for all natural-resource problems (Ostrom et al. 2007); but it does provide a desperately needed mechanism to enhance communication among stakeholders. Effective implementation of collaborative adaptive management requires that substantial institutional barriers be overcome and that meaningful incentives be put in place to promote its development. We recommend that the profession initiate a more comprehensive evaluation of complex adaptive systems by integrating both the social and biophysical components of rangelands, including the diverse knowledge sources of managers, agency professionals, and researchers, to replace the narrow technological approach to grazing systems. An adaptive management framework that explicitly incorporates and evaluates both experiential and experimental knowledge can most effectively facilitate the learning required to create management strategies that fit specific social and ecological settings and that accommodate the inherent uncertainties of rangeland ecosystems.

\section{ACKNOWLEDGMENTS}

We wish to thank the associate editor, Leigh Hunt, and three anonymous reviewers for constructive and insightful contributions to this manuscript.

\section{LITERATURE CITED}

Balley, D. W., AND J. R. BRown. 2011. Rotational grazing systems and livestock grazing behavior in shrub-dominated semi-arid and arid rangelands. Rangeland Ecology \& Management 64:1-9.

Bartolome, J. 1989. Book review: holistic resource management by Allan Savory. Journal of Soil and Water Conservation 44:591-592.

BentLEY, H. L. 1902. Experiments in range improvement in central Texas. Washington, DC, USA: Government Printing Office. US Forest Service Bulletin No. $13.72 \mathrm{p}$.

BLACKMORE, C. 2007. What kinds of knowledge, knowing and learning are required for addressing resource dilemmas?: a theoretical overview. Environmental Science \& Policy 10:512-525.

Boyd, C. S., AND T. J. SveJCAR. 2009. Managing complex problems in rangeland ecosystems. Rangeland Ecology \& Management 62:491-499.

Briske, D. D., J. D. Derner, J. R. Brown, S. D. Fuhlendorf, W. R. Teague, K. M. Havstad, R. L. Gillen, A. J. Ash, and W. D. Willms. 2008. Rotational grazing on rangelands: reconciliation of perception and experimental evidence. Rangeland Ecology \& Management 61:3-17.

Briske, D. D., S. D. Fuhlendorf, and F. E. Smeins. 2005. State-and-transition models, thresholds, and rangeland health: a synthesis of ecological concepts and perspectives. Rangeland Ecology \& Management 58:1-10.

Brunson, M. W., and E. A. BurRitt. 2009. Behavioral factors in rotational grazing systems. Rangelands 31:20-25.

Budd, B., AND J. ThoRpe. 2009. Benefits of managed grazing: a manager's perspective. Rangelands 31:11-14.

Bundy, A., R. Chuenpagdee, S. Jentoft, and R. Mahon. 2008. If science is not the answer, what is? An alternative governance model for the world fisheries. Frontiers in Ecology and the Environment 6:152-155.

Chapline, W. R., R. S. Campbell, R. Price, and G. Stewart. 1944. The history of Western range research. Agricultural History 18:127-143.

Clements, F. E. 1920. Plant indicators. Washington, DC, USA: Carnegie Institution of Washington. $388 \mathrm{p}$.

Cortner, H. J., M. G. Wallace, S. Burke, and M. A. Moote. 1998. Institutions matter: the need to address the institutional challenges of ecosystem management. Landscape and Urban Planning 40:159-166.
Derner, J. D., R. H. Hart, M. A. Smith, and J. W. Waggoner, JR. 2008. Long-term cattle gain responses to stocking rate and grazing systems in northern mixedgrass prairie. Livestock Science 117:60-69.

Dyksterhuis, E. J. 1955. What is range management? Journal of Range Management 8:193-196.

EluIs, J. E., AND D. M. Swift. 1988. Stability of African pastoral ecosystems: alternate paradigms and implications for development. Journal of Range Management 41:450-459.

Fazey, I., J. G. P. Gamarra, J. Fischer, M. S. Reed, L. C. Stringer, and M. Christie. 2010. Adaptation strategies for reducing vulnerability to future environmental change. Frontiers in Ecology and the Environment 8:414-422.

Fernandez-Gimenez, M. E., H. L. Ballard, and V. E. Sturtevant. 2008. Adaptive management and social learning in collaborative and community-based monitoring: a study of five community-based forestry organizations in the western USA. Ecology and Society 13(2):4. Available at: http://www. ecologyandsociety.org/vol13/iss2/art4/. Accessed 25 May 2010.

Fortmann, L. P., and S. K. Fairfax. 1989. American forestry professionalism in the Third World: some preliminary observations. Economic and Political Weekly August 12:267-272.

GoodLOE, S. 1969. Short duration grazing in Rhodesia. Journal of Range Management 22:369-373.

Grantham, H. S., M. Bode, E. Mcdonald-Madden, E. T. Game, A. T. Knight, and H. P. Possingham. 2010. Effective conservation planning requires learning and adaptation. Frontiers in Ecology and the Environment 8:431-437.

GrifFITHS, D. 1904. Range investigations in Arizona. Washington, DC, USA: Government Printing Office. US Department of Agriculture [USDA] Forest Service Bulletin No. 67. 62 p.

Heady, H. F. 1961. Continuous vs. specialized grazing systems: a review and application to California annual type. Journal of Range Management 14:182-193.

Heitschmidt, R. K., and C. A. Taylor, JR. 1991. Livestock production. In: R. K. Heitschmidt and J. W. Stuth [EDS.]. Grazing management: an ecological perspective. Portland, OR, USA: Timber Press. p. 161-177.

Holuing, C. S. 1978. Adaptive environmental assessment and management. London, United Kingdom: John Wiley \& Sons. 377 p.

Holuing, C. S. 1996. Surprise for science, resilience for ecosystems, and incentives for people. Ecological Applications 6:733-735.

Hormay, A. L., And A. B. Evanko. 1958. Rest-rotation grazing: a management system for bunchgrass ranges. Albany, CA, USA: USDA Forest Service California Forest and Range Experiment Station Misc. Paper 27.

Hughes, T. P., D. R. Bellwood, C. Folke, R. S. Steneck, and J. Wilson. 2005. New paradigms for supporting the resilience of marine ecosystems. Trends in Ecology and Evolution 20:380-386.

Jacobo, E. J., A. M. Rodríguez, N. Bartoloni, and V. A. Deregibus. 2006. Rotational grazing effects on rangeland vegetation at a farm scale. Rangeland Ecology \& Management 59:249-257.

JoyCE, L. A. 1993. The life cycle of the range condition concept. Journal of Range Management 46:132-138.

Juntti, M., D. Russel, and J. Turnpenny. 2009. Evidence, politics and power in public policy for the environment. Environmental Science \& Policy 12:207-215.

Kaufman, H. 1967. The forest ranger: a study in administrative behavior. Baltimore, MD, USA: Johns Hopkins University Press. 257 p.

KLEIN, J. T. 1996. Crossing boundaries: knowledge, disciplinarities and interdisciplinarities. Charlottesville, VA, USA: University of Virginia Press. $281 \mathrm{p}$.

LaunchBaugh, K. L., and J. W. WaLker. 2006. Targeted grazing-a new paradigm for livestock management. In: K. Launchbaugh, J. W. Walker, and R. J. Daines [EDS.]. Targeted grazing: a natural approach to vegetation management and landscape enhancement. Centennial, CO, USA: American Sheep Industry Association. p. 2-8.

Lave, R. 2009. The controversy over Natural Channel Design: substantive explanations and potential avenues for resolution. Journal of the American Water Resources Association 45:1519-1532.

Lele, S., and R. B. Norgaard. 2005. Practicing interdisciplinarity. BioScience 55:967-975. 
Likens, G. E., AND J. F. FrankLin. 2009. Ecosystem thinking in the northern forestand beyond. BioScience 59:511-513.

Lynam, T. J. P., and M. StafFord Smith. 2004. Monitoring in a complex worldseeking slow variables, a scaled focus, and speedier learning. African Journal of Range \& Forage Science 21:69-78.

McLain, R. J., AND R. G. LeE. 1996. Adaptive management: promises and pitfalls. Environmental Management 20:437-448.

MerRILL, L. B. 1954. A variation of deferred rotation grazing for use under southwest range conditions. Journal of Range Management 7:152-154.

MIlLeR, A. 1999. Environmental problem solving: psychosocial barriers to adaptive change. New York, NY, USA: Springer-Verlag. 238 p.

Molr, W. H., AND W. M. BLock. 2001. Adaptive management on public lands in the United States: commitment or rhetoric? Environmental Management 28:141-148.

Murray, C., and D. Marmorek. 2003. Adaptive management and ecological restoration. In: P. Freiderici [ED.]. Ecological restoration of southwestern Ponderosa pine forests. Washington, DC, USA: Island Press. p. 417-428.

Nichols, J. D., AND B. K. Williams. 2006. Monitoring for conservation. Trends in Ecology and Evolution 21:668-673.

Norton, B. E. 1998. The application of grazing management to increase sustainable livestock production. Animal Production in Australia 22:15-26.

Oba, G., N. C. Stenseth, and W. J. Lusigi. 2000. New perspectives on sustainable grazing management in arid zones of Sub-Saharan Africa. BioScience 50:35-51.

O'Reagain, P., J. Bushell, C. Holloway, and A. Reid. 2009. Managing for rainfall variability: effect of grazing strategy on cattle production in a dry tropical savanna. Animal Production Science 49:85-99.

O'Reagain, P. J., And J. R. Turner. 1992. An evaluation of the empirical basis for grazing management recommendations for rangeland in South Africa. Journal of the Grassland Society of South Africa 9:38-49.

Ostrom, E., M. A. Janssen, and J. M. Anderies. 2007. Going beyond panaceas. Proceedings of the National Academy of Sciences 104:15176-15178.

ParkeR, K. W. 1967. Arthur W. Sampson-pioneer range scientist: portrait of the man. Journal of Range Management 20:346-347.

Pinchak, W. E., W. R. Teague, R. J. Ansley, J. A. Waggoner, and S. L. Dowhower. 2010. Integrated grazing and prescribed fire restoration strategies in a mesquite savanna: III. ranch-scale cow-calf production responses. Rangeland Ecology \& Management 63:298-307.

Pullin, A. S., T. M. Knight, D. A. Stone, and K. Charman. 2003. Do conservation managers use scientific evidence to support their decision-making? Biological Conservation 119:245-252.

Richards, C., and G. LaWrence. 2009. Adaptation and change in Queensland's rangelands: cell grazing as an emerging ideology of pastoral-ecology. Land Use Policy 26:630-639.

Rissman, A. R., And N. F. Sayre. 2011. Conservation outcomes and social relations: a comparative study of private ranchland conservation easements. Society and Natural Resources (in press).

RowLEY, W. D. 1985. U.S. Forest Service grazing and rangelands: a history. College Station, TX, USA: Texas A\&M University Press. 270 p.

Sampson, A. W. 1913. Range improvement by deferred and rotation grazing. Washington, DC, USA: Government Printing Office. USDA Bulletin 34.

Sampson, A. W. 1919. Plant succession in relation to range management. Washington, DC, USA: Government Printing Office. USDA Bulletin 791. 76 p.

Sampson, A. W. 1923. Range and pasture management. New York, NY, USA: John Wiley \& Sons. $421 \mathrm{p}$.

Sampson, A. W. 1951. A symposium on rotation grazing in North America. Journal of Range Management 4:19-24.

Sampson, A. W. 1952. Range management, principles, and practices. New York, NY, USA: John Wiley \& Sons. 579 p.

SAVORY, A. 1988. Holistic resource management. Washington, DC, USA: Island Press. $545 \mathrm{p}$.

Sayre, N. F. 2010. Climax and "original capacity": the science and aesthetics of ecological restoration in the southwestern USA. Ecological Restoration 28:23-31.
Sayre, N. F., and M. Fernandez-Gimenez. 2003. The genesis of range science, with implications for pastoral development policy. In: N. Allsopp, A. R. Palmer, S. J. Milton, K. P. Kirkman, G. I. H. Kerley, C. R. Hurt, and C. J. Brown [eds.]. Proceedings of the VIIth International Rangeland Congress; 26 July-1 August 2003; Durban, South Africa. Durban, South Africa: Document Transformation Technologies. p. 1976-1985.

SCHIFF, A. 1962. Fire and water: scientific heresy in the forest service. Boston, MA, USA: Harvard University Press. 225 p.

Shrader-Frechette, K. S., and E. D. McCoy. 1993. Method in ecology: strategies for conservation. New York, NY, USA: Cambridge University Press. 328 p.

Sмiтh, J. G. 1899. Grazing problems in the southwest and how to meet them. Washington, DC, USA: US Government Printing Office. USDA Division of Agrostology Bulletin 16. $62 \mathrm{p}$.

[SRM] Society for Range Management. T. E. Bedell [ed.]. 1998. A glossary of terms used in range management. 4th ed. Lakewood, CO, USA: SRM. $32 \mathrm{p}$.

Stafford Smith, D. M., G. M. McKeon, I. W. Watson, B. K. Henry, G. S. Stone, W. B. Hall, and S. M. Howden. 2007. Learning from episodes of degradation and recovery in variable Australian rangelands. Proceedings National Academy of Science of the USA 104:20690-20695.

Stankey, G. H., B. T. Bormann, C. Ryan, B. Shindler, V. Sturtevant, R. N. Clark, and C. Philpot. 2003. Adaptive management and the Northwest Forest Plan: rhetoric and reality. Journal of Forestry January/February:40-46.

StaRRS, P. F. 1998. Let the cowboy ride: cattle ranching in the American West. Baltimore, MD, USA: Johns Hopkins University Press. 386 p.

Stern, P. C. 2005. Deliberative methods for understanding environmental systems. BioScience 55:976-982.

Stoddart, L. A., and A. D. Smith. 1955. Range management. New York, NY, USA: McGraw-Hill. 433 p.

Sutherland, W. J., A. S. Pullin, P. M. Dolman, and T. M. Knight. 2004. The need for evidence-based conservation. Trends in Ecology and Evolution 19:305-308.

Teague, W. R., S. L. Dowhower, R. J. Ansley, W. E. Pinchak, and J. A. Waggoner. 2010. Integrated grazing and prescribed fire restoration strategies in a mesquite savanna: I. vegetation responses. Rangeland Ecology \& Management 63:275-285.

Teague, W. R., S. L. Dowhower, and J. A. Waggoner. 2004. Drought and grazing patch dynamics under different grazing management. Journal of Arid Environments 58:97-117.

Teague, W. R., F. Provenza, B. Norton, T. Steffens, M. Barnes, M. Kothmann, and R. RоAтH. 2008. Benefits of multi-paddock grazing management on rangelands: limitations of experimental grazing research and knowledge gaps. In: H. Schröder [ED.]. Grasslands: ecology, management and restoration. Hauppauge, NY, USA: Nova Science Publishers. p. 41-80.

Thompson, J. L. 2007. Interdisciplinary team dynamics: a systems approach to understanding communication and collaboration in complex teams. Saarbrücken, Germany: VDM Verlag Dr. Müller Press. $324 \mathrm{p}$.

ToBEY, R. C. 1981. Saving the prairies: the life cycle of the founding school of American plant ecology, 1895-1955. Berkeley, CA, USA: University of California Press. 315 p.

Toombs, T. P., and M. G. Roberts. 2009. Are Natural Resources Conservation Service range management investments working at cross-purposes with wildlife habitat goals on western United States rangelands? Rangeland Ecology \& Management 62:351-355.

Torell, L. A., S. Murugan, and 0. A. Ramirez. 2010. Economics of flexible versus conservative stocking strategies to manage climate variability risk. Rangeland Ecology \& Management 63:415-425.

Walters, C. J., AND C. S. Holling. 1990. Large-scale management experiments and learning by doing. Ecology 71:2060-2068.

Westoby, M., B. H. Walker, And I. Noy-MeIR. 1989. Opportunistic management for rangelands not at equilibrium. Journal of Range Management 42:266-274.

Wooton, E. 0. 1908. The range problem in New Mexico. Las Cruces, NM, USA: New Mexico College of Agriculture and Mechanic Arts. Agriculture Experiment Station Bulletin 66. 46 p. 